\title{
KAJIAN KUAT TARIK LANGSUNG DAN KUAT LEKAT PADA BETON MUTU TINGGI MEMADAT MANDIRI DENGAN VARIASI KADAR METAKAOLIN
}

\author{
Wibowo'), Sunarmasto ${ }^{2)}$, Huesca Rashad ${ }^{3)}$ \\ 1), 2) Dosen Program Studi Teknik Sipil Fakultas Teknik Universitas Sebelas Maret \\ 3) Mahasiswa Program Studi Teknik Sipil Fakultas Teknik Universitas Sebelas Maret \\ Jl. Ir. Sutami 36 A, Kentingan Surakarta 57126, Telp (0271) 647069, Fax 662118 \\ Email : huescaras@student.uns.ac.id
}

\begin{abstract}
The quality of High Strength Self Compacting Concrete keep getting better with many kinds of improvements, including by adding some pozzolanic admixture in concrete mixture including the pozzolanic admixture used in this research which is metakaolin. The purpose of this research focused on studying the effect of metakaolin addition on the parameter of SCC, direct tensile strength, and bond strength of HSSCC. This research use experimental method. The workability tests in this research include slump flow test for filling ability, $V$-funnel test for passing ability, and L-box test for segregation resistance. The direct tensile strength test and bond strength test is conducted by using Universal Testing Machine by holding and pulling the specimens until it reaches the maximum load. This study shows that metakaolin decreases the workability of the fresh concretes, but value of these concrete tests in this research still meets the standard of self compacting concrete. Both the direct tensile strength and bond strength of 28 days old concrete decreases by the addition of metakaolin with the lowest of both value is the concrete with metakaolin composition of 22,5\%.
\end{abstract}

Keywords: bond strength, direct tensile strength, High Strength Self Compacting Concrete, metakaolin, workability.

\begin{abstract}
Abstrak
Kualitas beton mutu tinggi memadat mandiri terus meningkat dengan berbagai inovasi, termasuk dengan penambahan bahan tambah yang bersifat pozolan pada campuran beton termasuk bahan tambah pozolan yang digunakan pada penelitian ini yakni metakaolin. Tujuan penelitian ini adalah untuk mengetahui pengaruh penambahan metakaolin terhadap parameter SCC, nilai kuat tarik langsung, dan kuat lekat beton HSSCC. Penelitian ini menggunakan metode eksperimental. Pengujian workability pada penelitian ini meliputi uji slump flow untuk mengukur filling ability, uji V-funnel untuk mengukur passing ability, dan uji Lbox untuk mengukur segregation resistance. Pengujian kuat tarik langsung, dan kuat lekat dilakukan dengan menggunakan Universal Testing Machine dengan menahan dan menarik benda uji mencapai beban maksimum. Penelitian ini menunjukkan bahwa metakaolin menurunkan workability beton segar, namun nilai dari pengujian beton ini masih memenuhi standar beton memadat mandiri. Baik kuat tarik langsung maupun kuat lekat beton mengalami penurunan seiring penambahan kadar metakaolin dengan nilai terendah pada beton dengan kadar metakaolin 22,5\%.
\end{abstract}

Kata Kunci : beton mutu tinggi memadat mandiri, kuat lekat, kuat tarik langsung, metakaolin, workability.

\section{PENDAHULUAN}

Beton adalah salah satu material yang sangat umum digunakan di sektor konstruksi karena memiliki bahan susun yang relatif mudah untuk didapatkan, bermutu tinggi, dan mudah dikerjakan. Banyaknya penggunaan beton mendorong berbagai inovasi yang dikembangkan untuk meningkatkan kualitas beton. Inovasi yang telah dikembangkan bermacam-macam, salah satunya ialah High Strength Self Compacting Concrete (HSSCC).

Mengacu pada penelitian sebelumnya, penggunaan metakaolin sebagai bahan pengganti semen pada beton dilakukan karena sifatnya sebagai pozzolan, yakni akan bereaksi dengan proses hidrasi semen dan partikel berukuran kecil sebagai pengisi pori-pori beton yang dapat meningkatkan kualitas beton, mempercepat proses hidrasi pada beton dan mengurangi kelemahan yang ada pada beton konvensional.

Beton pada umumnya memiliki kuat tekan yang tinggi, namun kuat tarik yang rendah. Kuat tarik beton yang rendah dapat dibantu dengan baja tulangan yang mempunyai daya tarik lebih baik daripada beton. Beton yang sudah ditambahkan baja tulangan ini dapat menahan momen pada bagian penampang beton yang biasanya retak akibat ketidakmampuan beton menahan kuat tarik yang berlebih. Apabila beton menggunakan tulangan, kedua komponen tersebut harus saling mengikat dan melekat. Hal ini dipengaruhi oleh kuat lekat antara beton dengan tulangan, yang dapat memastikan kedua elemen tersebut bekerja dengan sinergis.

Penghitungan desain beton biasanya berfokus pada kuat tekan beton tanpa terlalu memperhatikan kuat tarik dan kuat lekat yang sebenarnya merupakan hal penting yang dapat mempengaruhi ukuran beton dan besar retakan yang terjadi. Dengan penambahan metakaolin sebagai pengganti semen diharapkan dapat mengatasi masalah kompleksitas beton yang ada di kalangan konstruksi, meningkatkan mutu beton (kuat tekan, kuat tarik, dan kuat lekat), meningkatkan keawetan beton, dan mengurangi porositas dan permeabilitas beton. 


\section{Beton Mutu Tingi (High Strength Concrete)}

Menurut SNI 03-6468-2000, beton mutu tinggi didefinisikan sebagai beton yang memiliki kuat tekan yang disyaratkan, yakni lebih besar atau sama dengan 41,4 MPa. Faktor-faktor yang menentukan dalam upaya pembuatan beton mutu tinggi diantaranya ialah pemilihan bahan, rasio air dengan bahan bersifat semen, kelecakan, dan pengukuran kekuatan.

\section{Beton Memadat Mandiri (Self Compacting Concrete)}

Beton memadat mandiri merupakan beton yang mampu mengalir dengan beratnya sendiri dan tidak memerlukan proses penggetaran seperti pada beton normal karena mampu memenuhi atau mengisi bekisting dan mencapai kepadatan tertingginya. Keuntungan yang dapat diperoleh dari penggunaan SCC antara lain dapat mengurangi lamanya proses konstruksi dan upah pekerja, pemadatan dan penggetaran beton yang optimum, serta dapat mengurangi kebisingan yang dapat mengganggu lingkungan sekitarnya. Komposisi material SCC sendiri terdiri dari semen, agregat kasar, pasir, bahan pengisi (filler), air dan superplasticizer. Dalam pembuatan SCC ini, penggunaan filler dapat menggunakan fly ash, serbuk batu kapur, silica fume atau bahan lainnya yang mempunyai sifat pozzolan, yaitu dapat bereaksi dengan kapur bebas yang dilepaskan semen saat proses hidrasi dan membentuk senyawa yang bersifat mengikat pada temperatur normal dengan adanya air sehingga akan mengurangi porositas yang terjadi pada beton (Herbudiman dan Siregar, 2013).

\section{Metakaolin}

Metakaolin merupakan hasil pembakaran (kalsinasi) dari kaolin pada suhu 4500C- 9000C yang mempunyai ukuran partikel lebih kecil dari silica fume dan banyak mengandung $\mathrm{SiO} 2$ dan $\mathrm{A} 2 \mathrm{O} 3$ (pozzolan) yang merupakan unsur utama penyusun semen sehingga digunakan sebagai bahan pengganti semen (Sambowo, 2002).

\section{Kuat Tarik Langsung}

Kuat tarik adalah ukuran kuat beton yang diakibatkan oleh suatu gaya yang cenderung memisahkan sebagian beton akibat tarikan. Kuat tarik beton berkisar 1/18 dari kuat desak pada waktu umurnya masih muda, dan berkisar 1/20 sesudahnya. Kuat tarik juga merupakan bagian penting didalam menahan retakan akibat perubahan kadar air dan suhu. Pengujian kuat tarik biasanya diadakan untuk

pembuatan konstruksi jalan raya dan lapangan terbang (Murdock dan Brook, 1991).

Kuat tarik beton bisa didapatkan dengan beberapa pengujian, salah satunya ialah dengan uji kuat tarik langsung. Pengujian kuat tarik langsung dilakukan dengan membuat benda uji dengan modifikasi berupa grip dari baja pada kedua ujungnya. Benda uji akan ditarik dari kedua ujung lewat grip yang ada pada bagian luar beton. Nilai kuat tarik yang diperoleh didapatkan berdasarkan hasil penghitungan dari besar beban tarik maksimum $(\mathrm{N})$ dibagi dengan luas penampang yang terkecil $\left(\mathrm{mm}^{2}\right)$.

Penelitian tentang kuat tarik langsung jarang dilakukan karena persiapan dan pelaksanaan pengujian sangat sulit. Faktor utama permasalahan pengujian kuat tarik langsung ialah kedua ujung benda uji yang biasa disebut sebagai grip. Kuat tarik langsung beton biasanya dikonversikan dari hasil uji kuat tarik belah atau uji kuat lentur, namun hasil konversi ini tidak dapat digunakan untuk beton SCC, meskipun sebenarnya kuat tarik langsung mempengaruhi defleksi, retakan, sobekan, dan kelekatan dari beton SCC (Alhussainy et al, 2016).

\section{Kuat Lekat}

Kuat lekat merupakan kombinasi kemampuan antara baja tulangan dan beton yang menyelimutinya dalam menahan gaya-gaya yang dapat menyebabkan lepasnya lekatan antara baja tulangan dan beton (Winter dan Salmon, 1993).

Kuat lekat antara beton dan baja bisa didapatkan dengan berbagai jenis pengujian yang berbeda, diantaranya ialah dengan melakukan beam test, embedded rod test dan juga metode pengujian yang akan dilakukan pada penelitian ini, yakni pull-out test yang akan dilakukan pada benda uji beton silinder yang memiliki tulangan berupa baja.

Metode pull-out test dapat memberikan perbedaan yang signifikan antara efisiensi lekatan berbagai jenis permukaan tulangan dan panjang penanamannya (embedment length), akan tetapi hasil dari pengujian ini belum memberikan tegangan lekat sesungguhnya pada struktur rangka. Metode pull-out test menghasilkan beton yang mengalami tekan dan baja yang mengalami tarik, dimana beton dan baja di sekelilingnya mengalami tegangan yang sama (Nawi, 1998). 


\section{METODE}

Metode penelitian yang digunakan pada penelitian ini ialah metode eksperimental untuk mengkaji kuat tarik langsung, kuat lekat, dan workability beton mutu tingi memadat mandiri. Pengujian yang dilakukan untuk workability ialah Slump flow test, $V$-funnel test, dan L-box test pada beton segar. Pengujian kuat tarik langsung dan kuat lekat dilakukan terhadap beton berumur 28 hari dengan bentuk berupa balok 10x10x50 cm untuk uji kuat tarik langsung dan silinder berdiameter $15 \mathrm{~cm}$ dan tingggi $25 \mathrm{~cm}$ untuk uji kuat lekat. Komposisi metakaolin yang digunakan ialah $0 \%$; $12,5 \% ; 15 \% ; 17,5 \% ; 20 \%$; dan 22,5\%. Jumlah benda uji tiap kadar yang digunakan dapat dilihat pada Tabel 1.

Tabel 1. Nama dan Jumlah Benda Uji

\begin{tabular}{cccc}
\hline $\begin{array}{c}\text { Kadar } \\
\text { Metakaolin }\end{array}$ & $\begin{array}{c}\text { Nama } \\
\text { Benda Uji }\end{array}$ & $\begin{array}{c}\text { Umur } \\
\text { (hari) }\end{array}$ & Jumlah \\
\hline \multicolumn{4}{c}{ Kuat Tarik Langsung } \\
\hline $0 \%$ & HSSCC-KT-MK 0 & 28 & 3 \\
\hline $12,5 \%$ & HSSCC-KT-MK 12,5 & 28 & 3 \\
\hline $15 \%$ & HSSCC-KT-MK 15 & 28 & 3 \\
\hline $17,5 \%$ & HSSCC-KT-MK 17,5 & 28 & 3 \\
\hline $20 \%$ & HSSCC-KT-MK 20 & 28 & 3 \\
\hline $22,5 \%$ & HSSCC-KT-MK 22,5 & 28 \\
\hline Kadar & Nama & Umur & Jumlah \\
Metakaolin & Benda Uji & (hari) & Kuat Lekat \\
\hline \multicolumn{4}{c}{28} \\
\hline $0 \%$ & HSSCC-KL-MK 0 & 3 \\
\hline $12,5 \%$ & HSSCC-KL-MK 12,5 & 28 \\
\hline $15 \%$ & HSSCC-KL-MK 15 & 28 \\
\hline $17,5 \%$ & HSSCC-KL-MK 17,5 & 28 \\
\hline $20 \%$ & HSSCC-KL-MK 20 & 28 \\
\hline $22,5 \%$ & HSSCC-KL-MK 22,5 & 28 \\
\hline \multicolumn{5}{c}{ TOTAL BENDA UJI } \\
\hline
\end{tabular}

\section{Mix Design}

Rancangan campuran adukan beton mutu tinggi memadat mandiri dengan variasi komposisi metakaolin dibuat berdasarkan EFNARC 2002. Perbandingan agregat halus dan kasar yang digunakan ialah $51 \%: 49 \%$, total berat binder sebesar $600 \mathrm{~kg} / \mathrm{m}^{3}$, faktor air semen yang digunakan adalah 0,31 dan kadar optimum superplasticizer sebanyak $1,9 \%$ dari berat binder. Rekapitulasi rancangan campuran adukan beton yang digunakan pada penelitian ini dapat dilihat pada Tabel 2.

Tabel 2. Rekapitulasi Rancangan Campuran Adukan Beton (Mix Design Beton)

\begin{tabular}{ccccccc}
\hline $\begin{array}{c}\text { Kadar } \\
\text { Metakaolin }\end{array}$ & $\begin{array}{c}\text { Agregat } \\
\text { Halus } \\
(\mathbf{K g} / \mathbf{m} 3)\end{array}$ & $\begin{array}{c}\text { Agregat } \\
\text { Kasar } \\
(\mathbf{K g} / \mathbf{m} 3)\end{array}$ & $\begin{array}{c}\text { Semen } \\
\left.\mathbf{( K g} / \mathbf{m}^{3}\right)\end{array}$ & $\begin{array}{c}\text { Metakaolin } \\
\left(\mathbf{K g} / \mathbf{m}^{3}\right)\end{array}$ & $\begin{array}{c}\text { Superplasticizer } \\
\left(\mathbf{l t} / \mathbf{m}^{3}\right)\end{array}$ & $\begin{array}{c}\text { Air } \\
\left(\mathbf{l t} / \mathbf{m}^{3}\right)\end{array}$ \\
\hline $0 \%$ & 821,98 & 796,06 & 600,00 & 0,00 & 11,40 & 186,00 \\
\hline $12,5 \%$ & 815,96 & 790,23 & 525,00 & 75,00 & 11,40 & 186,00 \\
\hline $15 \%$ & 814,76 & 789,06 & 510,00 & 90,00 & 11,40 & 186,00 \\
\hline $17,5 \%$ & 813,55 & 787,90 & 495,00 & 105,00 & 11,40 & 186,00 \\
\hline $20 \%$ & 812,35 & 786,73 & 480,00 & 120,00 & 11,40 & 186,00 \\
\hline $22,5 \%$ & 811,15 & 785,57 & 465,00 & 135,00 & 11,40 & 186,00 \\
\hline
\end{tabular}

\section{Pengujian Beton Segar}

Pengujian pada beton segar dilakukan untuk memastikan beton memenuhi standar sebagai beton memadat mandiri, serta untuk mengetahui pengaruh penambahan kadar metakaolin terhadap workability beton. Parameter beton memadat mandiri pada penelitian ini adalah filling ability, passing ability dan segregation resistance yang diuji dengan pengujian slump flow, pengujian $V$-funnel, dan pengujian $L$-box yang dilakukan berdasarkan ketentuan EFNARC 2002.

\section{Pengujian Kuat Tekan}

Pengujian kuat tekan dilakukan untuk memastikan beton memenuhi standar sebagai beton mutu tinggi. Pengujian kuat tekan pada penelitian ini dilakukan berdasarkan SNI 6468-2000 dengan ketentuan kuat tekan beton harus melebihi 41,4 MPa. 


\section{Pengujian Kuat Tarik Langsung}

Pengujian kuat tarik langsung dilakukan dengan menggunakan Universal Testing Machine (UTM) dengan menarik beton melalui salah satu grip hingga beton atau grip mengalami kegagalan. Nilai kuat tarik langsung dapat dihitung dengan Persamaan [1].

$$
f_{c t}=\frac{P}{A}
$$

keterangan :

$f_{c t}=$ kuat tarik beton $\quad(\mathrm{MPa})$

$\mathrm{P}=$ beban tarik $\quad(\mathrm{N})$

$\mathrm{A}=$ luas bidang $\quad\left(\mathrm{mm}^{2}\right)$

\section{Pengujian Kuat Lekat}

Pengujian kuat lekat dilakukan dengan menggunakan Universal Testing Macbine (UTM) dengan menarik beton melalui baja tulangan hingga beton atau baja tulangan mengalami kegagalan. Nilai kuat lekat dapat dihitung dengan Persamaan [2].

$$
f^{\prime} b=\frac{P}{\operatorname{Ld} \times \pi \times \mathrm{Db}}
$$

keterangan :

$f^{\prime \prime} b=$ kuat lekat beton

$\mathrm{P}=$ beban tarik

$(\mathrm{MPa})$

$\mathrm{Ld}=$ panjang penyaluran $(\mathrm{mm})$

$\mathrm{Db}=$ diameter baja $\quad(\mathrm{mm})$

\section{HASIL DAN PEMBAHASAN}

Hasil Pengujian Beton Segar

Hasil pengujian beton segar pada penelitian ini dapat dilihat pada Tabel 3-5.

\begin{tabular}{|c|c|c|c|c|c|c|c|c|}
\hline $\begin{array}{c}\text { Kadar } \\
\text { Metakaolin }\end{array}$ & $\begin{array}{c}T_{500} \text { Re- } \\
\text { rata } \\
\text { (detik) }\end{array}$ & Syarat & Ket. & $\begin{array}{c}\mathrm{D}_{1} \\
(\mathrm{~mm})\end{array}$ & $\begin{array}{c}\mathrm{D}_{2} \\
(\mathrm{~mm})\end{array}$ & $\begin{array}{c}\text { D Rerata } \\
(\mathrm{mm})\end{array}$ & Syarat & Ket. \\
\hline $0 \%$ & 2,21 & \multirow{6}{*}{ 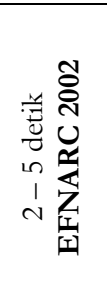 } & $\mathrm{V}$ & 750 & 760 & 755 & \multirow{6}{*}{ 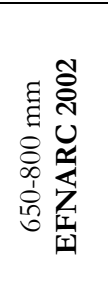 } & $\mathrm{V}$ \\
\hline $12,5 \%$ & 2,53 & & V & 740 & 760 & 750 & & $\mathrm{~V}$ \\
\hline $15 \%$ & 2,73 & & $\mathrm{~V}$ & 740 & 745 & 742,5 & & $\mathrm{~V}$ \\
\hline $17,5 \%$ & 2,89 & & $\mathrm{~V}$ & 730 & 750 & 740 & & $\mathrm{~V}$ \\
\hline $20 \%$ & 3,14 & & $\mathrm{~V}$ & 730 & 740 & 735 & & $\mathrm{~V}$ \\
\hline $22,5 \%$ & 3,47 & & $\mathrm{~V}$ & 700 & 730 & 715 & & $\mathrm{~V}$ \\
\hline
\end{tabular}

Tabel 3. Hasil Pengujian Slump flow

Keterangan $: \mathrm{V}=$ memenuhi syarat

\begin{tabular}{|c|c|c|c|}
\hline $\begin{array}{c}\text { Kadar } \\
\text { Metakaolin }\end{array}$ & $\begin{array}{l}\text { Waktu } \\
\text { (detik) }\end{array}$ & Syarat & Ket. \\
\hline $0 \%$ & 10,31 & \multirow{6}{*}{ 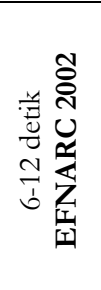 } & $\mathrm{V}$ \\
\hline $12,5 \%$ & 10,51 & & V \\
\hline $15 \%$ & 11,27 & & V \\
\hline $17,5 \%$ & 12 & & V \\
\hline $20 \%$ & 12,26 & & $\mathrm{X}$ \\
\hline $22,5 \%$ & 14 & & X \\
\hline
\end{tabular}

Tabel 4. Hasil Pengujian $V$-funnel

Keterangan : $\mathrm{V}=$ memenuhi syarat

$\mathrm{X}=$ tidak memenuhi syarat

\begin{tabular}{|c|c|c|c|c|c|}
\hline $\begin{array}{c}\text { Kadar } \\
\text { Metakaolin }\end{array}$ & $\begin{array}{c}\mathrm{h}_{2} \\
(\mathrm{~mm})\end{array}$ & $\begin{array}{c}\mathrm{h}_{1} \\
(\mathrm{~mm})\end{array}$ & $\mathbf{h}_{2} / \mathbf{h}_{1}$ & Syarat & Ket. \\
\hline $0 \%$ & 9 & 9,5 & 0,947 & \multirow{6}{*}{ 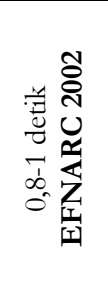 } & $\mathrm{V}$ \\
\hline $12,5 \%$ & 8,5 & 9 & 0,944 & & $\mathrm{~V}$ \\
\hline $15 \%$ & 8,5 & 9 & 0,944 & & V \\
\hline $17,5 \%$ & 8 & 8,5 & 0,941 & & V \\
\hline $20 \%$ & 8 & 9,5 & 0,842 & & $\mathrm{~V}$ \\
\hline $22,5 \%$ & 8 & 9,5 & 0,842 & & V \\
\hline
\end{tabular}

Tabel 5. Hasil Pengujian L-box

Keterangan : $\mathrm{V}=$ memenuhi syarat

Berdasarkan Tabel 3-5, semua jenis kadar memenuhi persyaratan kecuali kadar 20\% dan 22,5\% yang pengujian $V$ funnel nya membutuhkan waktu lebih dari 12 detik. Pengaruh penambahan kadar metakaolin pada workability beton dapat lebih mudah dipahami dengan mengamati grafik hubungan parameter SCC dengan variasi komposisi metakaolin yang dibuat berdasarkan Tabel 3-5, grafik tersebut dapat dilihat pada Gambar 1-4. 


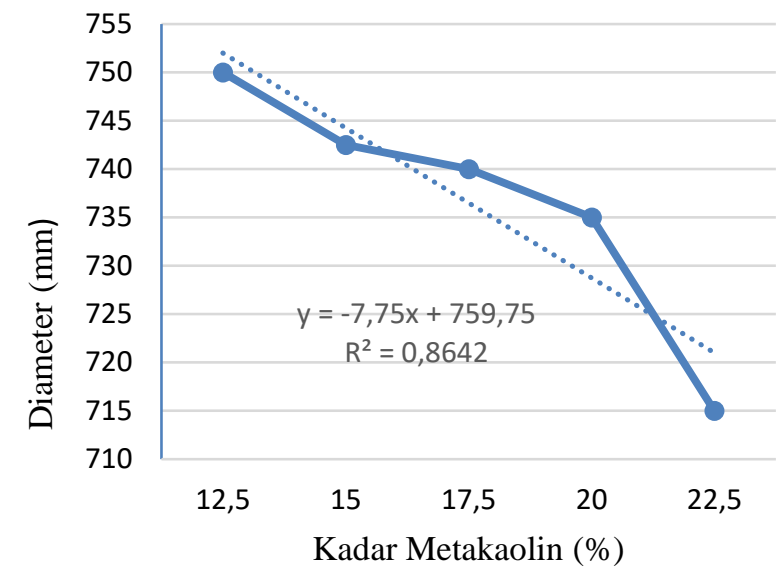

Gambar 1. Grafik Diameter Rerata Slump flow

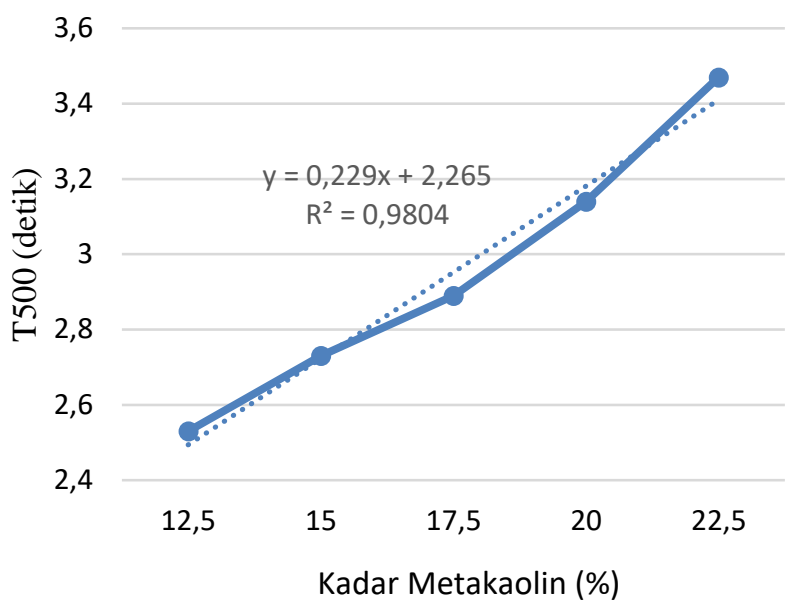

Gambar 2. Grafik Waktu Alir Slump flow

Berdasarkan Gambar 1, dapat dilihat bahwa penambahan kadar metakaolin menurunkan diameter Slump flow dan pada Gambar 2, penambahan kadar metakaolin memperlambat waktu alir Slump flow.

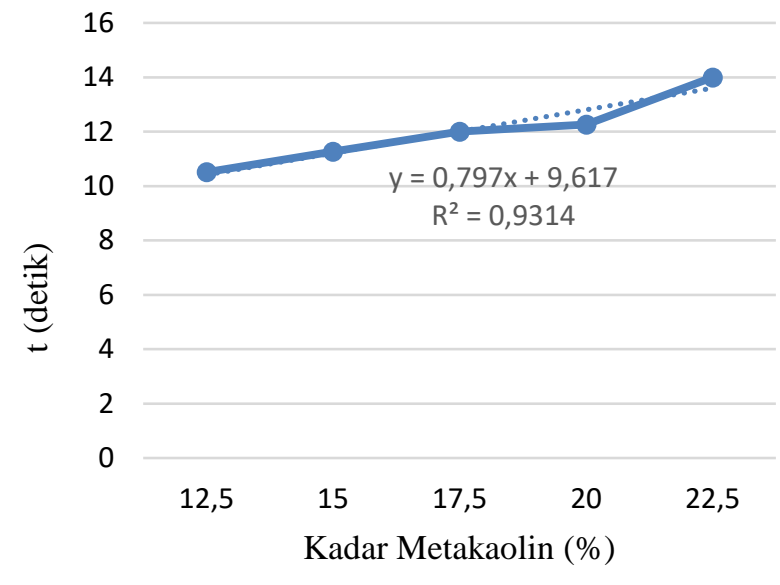

Gambar 3. Grafik Nilai V-Funnel

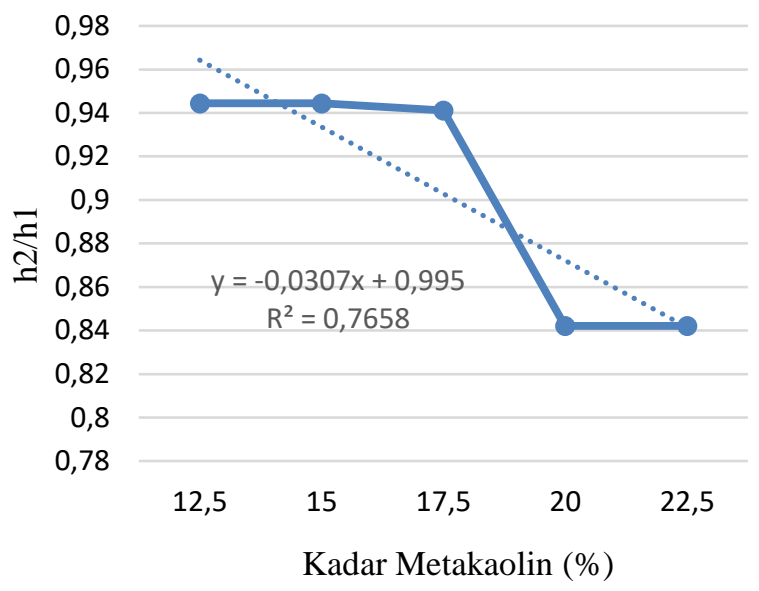

Gambar4. Grafik Nilai L-box

Berdasarkan Gambar 3, dapat dilihat bahwa penambahan kadar metakaolin memperlambat waktu alir $V$-funnel, dan pada Gambar 4, penambahan kadar metakaolin menurunkan h2/h1 L-box.

Dari semua grafik diatas dapat disimpulkan bahwa penambahan kadar metakaolin menurunkan workability beton.

\section{Hasil Pengujian Kuat Tekan Beton}

Hasil pengujian kuat tekan beton pada penelitian ini dapat dilihat pada Tabel 6.

Tabel 6. Hasil Pengujian Kuat Tekan Beton

\begin{tabular}{|c|c|c|c|}
\hline $\begin{array}{c}\text { Kadar } \\
\text { Metakaolin }\end{array}$ & $\begin{array}{c}\text { Kuat } \\
\text { Tekan } \\
\text { (MPa) }\end{array}$ & Syarat & Keterangan \\
\hline $0 \%$ & 46,798 & \multirow{6}{*}{ 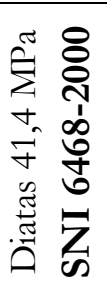 } & Memenuhi Syarat \\
\hline $12,5 \%$ & 50,094 & & Memenuhi Syarat \\
\hline $15 \%$ & 51,601 & & Memenuhi Syarat \\
\hline $17,5 \%$ & 59,699 & & Memenuhi Syarat \\
\hline $20 \%$ & 51,977 & & Memenuhi Syarat \\
\hline $22,5 \%$ & 45,198 & & Memenuhi Syarat \\
\hline
\end{tabular}

Berdasarkan Tabel 6, semua jenis kadar metakaolin memenuhi syarat SNI 6468-2000 sebagai beton mutu tinggi karena memiliki kuat tekan diatas 41,4 $\mathrm{MPa}$. 


\section{Hasil Pengujian Kuat Tarik Langsung Beton}

Pengujian kuat tarik langsung menghasilkan beban dalam bentuk Newton yang kemudian dihitung dengan dimensi benda uji nya berdasarkan persamaan yang sudah ditetapkan sehingga menghasilkan kuat tarik langsung dalam bentuk MPa, kemudian dihitung perbedaannya dengan kadar lainnya. Hasil pengujian kuat tarik langsung beton pada penelitian ini dapat dilihat pada Tabel 7.

Tabel 7. Hasil Pengujian Kuat Tarik Langsung Beton

\begin{tabular}{|c|c|c|c|c|c|c|c|}
\hline Nama Benda Uji & $\begin{array}{c}\text { Kode } \\
\text { Benda } \\
\text { Uji }\end{array}$ & $\begin{array}{l}\text { Lebar } \\
(\mathrm{mm})\end{array}$ & $\begin{array}{c}\text { Panjang } \\
(\mathrm{mm})\end{array}$ & $\begin{array}{c}\text { Beban } \\
\text { Maksimum } \\
\text { (N) }\end{array}$ & $\begin{array}{c}\text { Kuat Tarik } \\
\text { Langsung } \\
\text { (MPa) }\end{array}$ & $\begin{array}{c}\text { Kuat Tarik } \\
\text { Langsung } \\
\text { Rerata } \\
(\mathrm{MPa})\end{array}$ & $\begin{array}{c}\text { Kenaikan } \\
(\%)\end{array}$ \\
\hline \multirow{3}{*}{ HSSCC-KT-MK 0} & $\mathrm{~A}$ & 97 & 97 & 20290 & 3.49 & \multirow{3}{*}{3.52} & \multirow{3}{*}{-} \\
\hline & $\mathrm{B}$ & 60 & 100 & 21120 & 3.52 & & \\
\hline & $\mathrm{C}$ & 61 & 97 & 21050 & 3.56 & & \\
\hline \multirow{3}{*}{ HSSCC-KT-MK 12,5 } & A & 60 & 100 & 18070 & 3.01 & \multirow{3}{*}{3.22} & \multirow{3}{*}{-8.67} \\
\hline & B & 59 & 102 & 21520 & 3.58 & & \\
\hline & $\mathrm{C}$ & 62 & 103 & 19540 & 3.06 & & \\
\hline \multirow{3}{*}{ HSSCC-KT-MK 0} & A & 59 & 98 & 16690 & 2.89 & \multirow{3}{*}{3.14} & \multirow{3}{*}{-10.69} \\
\hline & B & 58 & 100 & 19200 & 3.31 & & \\
\hline & $\mathrm{C}$ & 61 & 99 & 19550 & 3.24 & & \\
\hline \multirow{3}{*}{ HSSCC-KT-MK 12,5 } & A & 62 & 102 & 20220 & 3.20 & \multirow{3}{*}{3.13} & \multirow{3}{*}{-11.10} \\
\hline & B & 60 & 102 & 19310 & 3.16 & & \\
\hline & $\mathrm{C}$ & 60 & 99 & 18050 & 3.04 & & \\
\hline \multirow{3}{*}{ HSSCC-KT-MK 0} & A & 62 & 99 & 17520 & 2.85 & \multirow{3}{*}{3.09} & \multirow{3}{*}{-12.18} \\
\hline & $\mathrm{B}$ & 59 & 99 & 19980 & 3.42 & & \\
\hline & $\mathrm{C}$ & 60 & 99 & 17830 & 3.00 & & \\
\hline \multirow{3}{*}{ HSSCC-KT-MK 12,5 } & A & 58 & 100 & 17830 & 3.07 & \multirow{3}{*}{3.04} & \multirow{3}{*}{-13.78} \\
\hline & $\mathrm{B}$ & 61 & 104 & 20070 & 3.16 & & \\
\hline & $\mathrm{C}$ & 64 & 98 & 18000 & 2.87 & & \\
\hline
\end{tabular}

Berdasarkan Tabel 7, dapat dilihat bahwa kuat tarik langsung dari beton tanpa metakaolin mengalami penurunan terus menerus terhadap penambahan kadar metakaolin yang ditetapkan, untuk lebih jelasnya dibuat grafik hubungan kuat tarik langsung dengan variasi komposisi metakaolin berdasarkan Tabel 7. Grafik tersebut dapat dilihat pada Gambar 5.

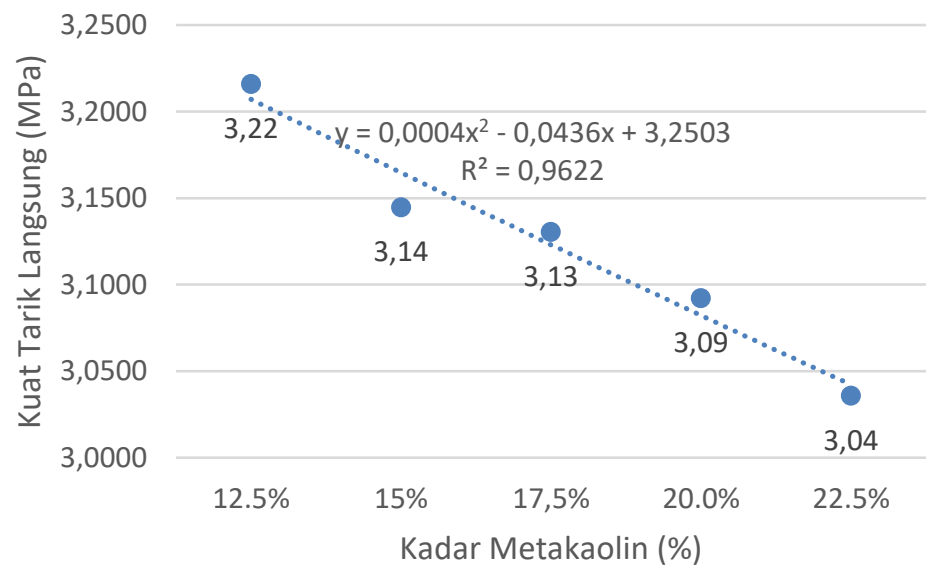

Gambar 5. Grafik Kuat Tarik Langsung

Berdasarkan Gambar 5, dapat dilihat bahwa kuat tarik langsung beton menurun dengan adanya penggantian berat semen dengan metakaolin kadar $12,5 \% ; 15 \% ; 17,5 ; 0 \%$; dan $22,5 \%$ dengan nilai berturut-turut 3,22 $\mathrm{MPa} ; 3,14$ $\mathrm{MPa} ; 3,13 \mathrm{MPa} ; 3,09 \mathrm{MPa}$; dan 3,04 MPa. 


\section{Hasil Pengujian Kuat Lekat Beton}

Pengujian kuat lekat menghasilkan beban dalam bentuk Newton yang kemudian dihitung dengan panjang penyaluran dan diameter bajaj yang digunakan berdasarkan persamaan yang sudah ditetapkan sehingga menghasilkan kuat lekat dalam bentuk MPa, kemudian dihitung perbedaannya dengan kadar lainnya. Hasil pengujian kuat lekat beton pada penelitian ini dapat dilihat pada Tabel 8 .

Tabel 8. Hasil Pengujian Kuat Lekat Beton

\begin{tabular}{|c|c|c|c|c|c|c|c|}
\hline Nama Benda Uji & $\begin{array}{c}\text { Kode } \\
\text { Benda } \\
\text { Uji }\end{array}$ & $\begin{array}{l}\text { Panjang } \\
\text { Penyaluran } \\
(\mathrm{mm})\end{array}$ & $\begin{array}{c}\text { Diameter } \\
\text { Baja } \\
(\mathrm{mm})\end{array}$ & $\begin{array}{c}\text { Beban } \\
\text { Maksimum } \\
(\mathbf{N})\end{array}$ & $\begin{array}{l}\text { Kuat } \\
\text { Lekat } \\
(\mathrm{MPa})\end{array}$ & $\begin{array}{c}\text { Kuat Lekat } \\
\text { Rerata } \\
(\mathrm{MPa})\end{array}$ & $\begin{array}{c}\text { Kenaikan } \\
(\%)\end{array}$ \\
\hline \multirow{4}{*}{ HSSCC-KT-MK 0} & A & 248 & 10 & 9022.44 & 1.16 & \multirow{4}{*}{1.16} & \multirow{3}{*}{ - } \\
\hline & B & 249 & 10 & 10395.4 & 1.33 & & \\
\hline & $\mathrm{C}$ & 250 & 10 & 7845.6 & 1.00 & & \\
\hline & A & 251 & 10 & 7649.46 & 0.97 & & \multirow{4}{*}{-13.78} \\
\hline \multirow[t]{3}{*}{ HSSCC-KT-MK 12,5 } & B & 251 & 10 & 7845.6 & 0.99 & \multirow[t]{2}{*}{1.00} & \\
\hline & $\mathrm{C}$ & 252 & 10 & 8237.88 & 1.04 & & \\
\hline & A & 251 & 10 & 7845.6 & 0.99 & & \\
\hline \multirow[t]{3}{*}{ HSSCC-KT-MK 0} & B & 250 & 10 & 7845.6 & 1.00 & \multirow[t]{3}{*}{0.98} & \multirow[t]{3}{*}{-15.58} \\
\hline & $\mathrm{C}$ & 250 & 10 & 7453.32 & 0.95 & & \\
\hline & A & 250 & 10 & 7061.04 & 0.90 & & \\
\hline \multirow[t]{3}{*}{ HSSCC-KT-MK 12,5 } & B & 249 & 10 & 7649.46 & 0.98 & \multirow[t]{3}{*}{0.93} & \multirow[t]{3}{*}{-19.75} \\
\hline & $\mathrm{C}$ & 251 & 10 & 7257.18 & 0.92 & & \\
\hline & A & 249 & 10 & 6864.9 & 0.88 & & \\
\hline \multirow[t]{3}{*}{ HSSCC-KT-MK 0} & B & 248 & 10 & 7453.32 & 0.96 & \multirow[t]{3}{*}{0.89} & \multirow[t]{3}{*}{-23.12} \\
\hline & $\mathrm{C}$ & 251 & 10 & 6668.76 & 0.85 & & \\
\hline & A & 251 & 10 & 7257.18 & 0.92 & & \\
\hline \multirow[t]{2}{*}{ HSSCC-KT-MK 12,5 } & B & 254 & 10 & 6668.76 & 0.84 & \multirow[t]{2}{*}{0.87} & \multirow[t]{2}{*}{-24.75} \\
\hline & $\mathrm{C}$ & 252 & 10 & 6864.9 & 0.87 & & \\
\hline
\end{tabular}

Berdasarkan Tabel 8, dapat dilihat bahwa kuat lekat dari beton tanpa metakaolin mengalami penurunan terus menerus terhadap penambahan kadar metakaolin yang ditetapkan, untuk lebih jelasnya dibuat grafik hubungan kuat lekat dengan variasi komposisi metakaolin berdasarkan Tabel 8. Grafik tersebut dapat dilihat pada Gambar 6.

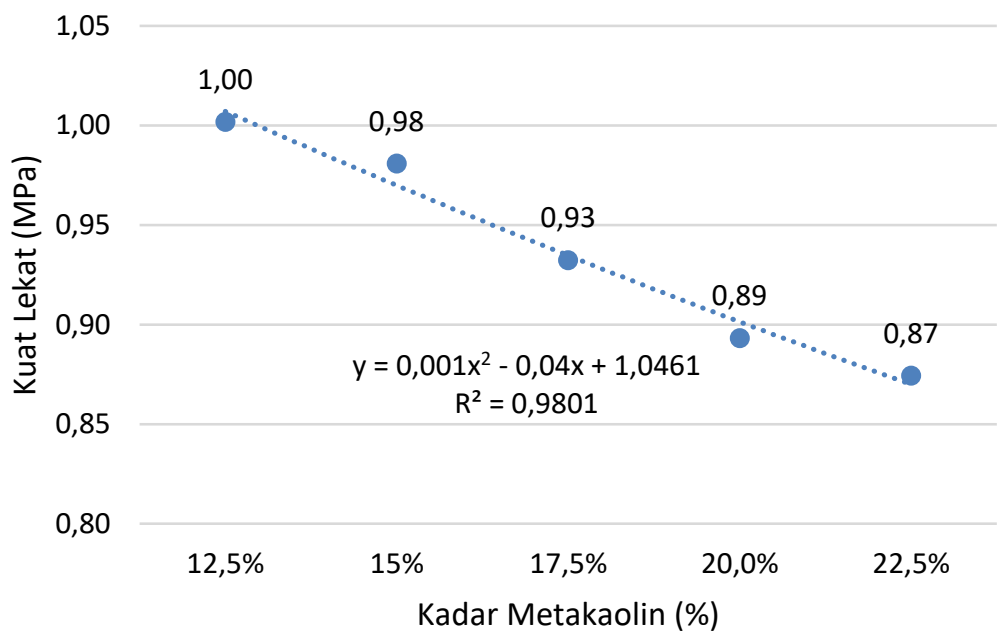

Gambar 6. Grafik Kuat Lekat

Berdasarkan Gambar 6, dapat dilihat bahwa kuat lekat beton menurun dengan adanya penggantian berat semen dengan metakaolin kadar $12,5 \% ; 15 \% ; 17,5 ; 0 \%$; dan 22,5\% dengan nilai berturut-turut 1,00 $\mathrm{MPa} ; 0,98 \mathrm{MPa}$; $0,93 \mathrm{MPa} ; 0,89 \mathrm{MPa} ;$ dan $0,87 \mathrm{MPa}$. 


\section{SIMPULAN}

Penelitian ini menghasilkan kesimpulan yang didapat berdasarkan hasil pengujian, pengolahan data, dan evaluasi yang telah dilakukan dengan kajian kuat lekan, kuat tarik langsung, dan kuat lekat beton mutu tinggi memadat mandiri dengan variasi komposisi metakaolin. Kesimpulan-kesimpulan tersebut ialah:

1. Semua beton yang dibuat pada penelitian ini memenuhi standar High Strength Concrete yakni diatas 41,4 MPa, baik pada beton tanpa metakaolin maupun pada beton dengan metakaolin. Penambahan kadar metakaolin pada beton yang digunakan pada penelitian ini meningkatkan kuat tekan dari beton-beton tersebut. Kuat tekan beton maksimum yang dicapai dengan penambahan kadar metakaolin pada penelitian ini ialah beton dengan penambahan kadar metakaolin sebesar 17,5\% dengan nilai kuat tekan sebesar 59,699 MPa dengan persentase peningkatan sebesar $27,565 \%$ dari kuat tekan beton tanpa metakaolin.

2. Penambahan variasi metakaolin pada campuran beton mutu tinggi memadat mandiri yang digunakan pada penelitian ini menurunkan workability beton, namun semua beton yang tersebut tetap mempertahankan sifat Self Compacting Concrete nya karena baik beton tanpa metakaolin maupun yang menggunakan metakaolin memenuhi parameter filling ability, passing ability, dan segregation resistance.

3. Kuat tarik langsung beton pada penelitian ini menurun seiring penambahan kadar metakaolin. Nilai kuat tarik langsung beton maksimum didapat dari beton tanpa penambahan metakaolin dengan nilai kuat tarik langsung sebesar 3,52 MPa, kemudian menurun seiring penambahan kadar metakaolin hingga penambahan kadar 22,5\% yang menghasilkan kuat tarik langsung terkecil, yakni sebesar 3,04 MPa. Kuat tarik langsung terkecil ini mengalami penurunan sebesar $13,78 \%$ dari beton tanpa metakaolin.

4. Kuat lekat antara beton dan tulangan pada penelitian ini menurun seiring penambahan kadar metakaolin. Nilai kuat lekat maksimum didapat dari beton tanpa penambahan metakaolin dengan nilai kuat lekat sebesar 1,16 MPa, kemudian menurun seiring penambahan kadar metakaolin hingga penambahan kadar 22,5\% yang menghasilkan kuat tarik langsung terkecil, yakni sebesar 0,87 MPa. Kuat tarik langsung terkecil ini mengalami penurunan sebesar $24,75 \%$ dari beton tanpa metakaolin.

\section{REKOMENDASI}

Penelitian ini memerlukan beberapa perbaikan sehingga penelitian selanjutnya dapat berjalan dengan lebih baik. Saran-saran untuk membantu penelitian selanjutnya berjalan dengan lebih baik diantaranya ialah:

1. Penelitian selanjutnya disarankan menggunakan benda uji yang lebih banyak dari penelitian ini sehingga hasil yang didapatkan lebih akurat, serta sebagai cadangan bila ada benda uji yang mengalami kerusakan.

2. Melakukan penelitian dengan umur umur beton yang lebih lama dari 28 hari, seperti 56 hari dan 90 hari untuk melihat dan membandingkan reaksi pozzolanik yang bekerja dan memastikan umur beton yang optimal.

\section{REFERENSI}

Alhussainy F. et al, 2016, "Direct Tensile Testing of Self-Compacting Concrete", University of Wollongong, Australia.

Anonim, 2000, "SNI 03-6468-2000 Tata Cara Perencanaan Campuran Tinggi Dengan Semen Portland Dengan Abu Terbang", Badan Standardisasi Nasional, Jakarta.

Anonim, 2002, EFNARC "Specification and Guidelines For Self-Compacting Concrete".

Herbudiman B. and Siregar S.E., 2013, "Kajian Interval Rasio Air-Powder Beton Self-Compating Terkait Kinerja Kekuatan dan Flow", Teknik Sipil Institut Teknologi Nasional, Bandung.

Murdock L.J. and Brook K.M., 1991, "Bahan dan Praktek Beton”, Erlangga, Jakarta.

Nawi E.G., 1998, "Beton Bertulang Suatu Pendekatan Dasar", Refika Aditama, Bandung.

Sambowo K.A., 2002, "Engineering Properties and Durability Performance of Metakaolin and Metakaolin-PFA Concrete", University of Sheffield, Ingggris.

Winter G. dan Salmon C.G., 1993, "Perencanaan Struktur Beton Bertulang”, Pradnya Paramita, Jakarta. 